DOI: $10.1515 /$ hssr-2015-0024

HSS IV.3 (2015)

\title{
Perennial Philology and the Ideal of the White Overall
}

José Augusto Cardoso Bernardes*

Centre of Portuguese Studies of University of Coimbra

\begin{abstract}
Joining the university context in the middle of the $19^{\text {th }}$ century, Philology served as a comprehensive basis for what nowadays is meant by literary and linguistic studies. Depending on the specialization tendency that would settle down in the academic context (with regard to either the formative offer or the foundation of various research fields), each of these areas followed separate or even divergent paths, losing, to a great extent, the contact with its initial basis. Despite this state of affairs, Philology has displayed a strong capacity of resistance, maintaining its traditional dimension active or going through metamorphoses that resulted from the incorporation of new technologies, as well as from the epistemological adjustment that enabled it to overcome its first positivist stages. Trying to find a new place inside the general framework of Social Sciences and Humanities, literary studies need to recover its order and credibility, two factors that the new face of Philology can inspire. The present study aims at reconstructing the most recent trajectory undergone by this field of research and education, by identifying a space of reconnection that already seems to be adequate and beneficial.
\end{abstract}

Keywords

Philology, Social Sciences, Humanities, Research, Education

\footnotetext{
* University of Coimbra, Faculty of Letters, Largo da Porta Férrea 3004-530 Coimbra, Portugal, augusto@ci.uc.pt
} 
José Augusto Cardoso Bernardes, Perennial Philology and the Ideal...

HSS, vol. IV, no. 3 (2015): 55-72

\section{Introduction}

We do not know how philologists dressed one hundred years ago when they were working on their papers. For want of other evidence, let us cautiously resort to photographs.

The only known pictures of D. Carolina (1852-1925) show her always wearing a suit, when giving classes in the Faculty of Letters of Coimbra, as well as when going out for a walk. The most relaxed photograph was taken while she was with her husband, her daughter-in-law and her two nephews, in the early summer of 1907 (Figure 1). The picture was taken outdoor, at the entrance of their house in Águas Santas. Joaquim de Vasconcelos seems to be wearing a white overall and D. Carolina is wearing, besides the skirt that touches the floor, a white blouse with frills. Therefore, the picture in which she appears as an intellectual is the one that shows her at the height of her career, sitting at her desk and wearing a suit and a hat (Figure 2). Are we supposed to believe that she was working dressed like that or was she only striking poses?

The same goes for Teófilo Braga (1843-1924), always immersed in piles of books, in loose and rolled sheets of paper. His hair might look slightly disheveled, but the tie, the waistcoat and the jacket are there (Figure 3). The handbooks of History present him as a tribune who opposed monarchy and a politician who was the leader of the Republican Provisional Government (1910-1911) and the Head of State (1915). However, what earned him fame was his crucial contribution to the foundation of a history of Portuguese literature ${ }^{1}$. He had a cautious and committed way of writing, almost sacerdotal. He died alone in his study and this solitary death seems to have a special meaning. It was as if he had died on the battlefield, fulfilling his supreme duty.

Finally, I shall make mention of the photograph of Anselmo Braamcamp Freire (1849-1921), a photograph that appears on the page that stands for the forward to the second edition of his "Gil Vicente, trovador, mestre da balança" (Figure 4). In this particular photograph the philologist has a white beard and he is extremely sober. He is holding the precious book and a young girl is standing next to him, looking at him affectionately, as well as in awe. This is a photograph that was taken after the completion of the above mentioned work. The desk he is sitting at is actually tidy, but the way he is looking at the book enables one to guess the 
José Augusto Cardoso Bernardes, Perennial Philology and the Ideal...

HSS, vol. IV, no. 3 (2015): 55-72

tremendous effort that allowed him to write his book and dedicate it to Maria Luisa, his goddaughter.

After all, although philologists work with patrimonial texts, they are not out of touch with reality. On the contrary, they are extremely active in the civic life. Braamcamp Freire is no exception. Unlike the two other personalities mentioned above, he never worked in the academic field. He was President of the Municipal Chamber of Lisbon, Deputy of the Constituent Assembly in 1911 and the first President of the Senate of the Portuguese Republic. Various statues have been erected in his honour and various streets have been named after him. This is due to the fact that he put forward a surprising and "invigorating" thesis, starting from documents that were regarded as "irrefutable". This thesis claims that Gil Vicente, the playwright that wrote, staged and assisted at the performance of 50 plays over a period of 35 years, also displayed a talent for jewelry. He touched the first gold coming from the Orient and in 1506 he moulded it into the famous Custódia de Belém².

It is worth noting that in those times people dressed up when they knew they were to appear in a photograph. Philologists, in particular, all had a special pose of marked probity that was in consonance with their profession: they were working with important documents on which they based their reliable inferences. Similar to what Renaissance humanists did, positivist philologists were constantly testing, by means of regular epistolary contacts ${ }^{3}$, the knowledge acquired.

\section{The lost ideal of Philology: issues in research and education}

Having this kind of support, one could assume that Philology had all the necessary conditions in order to assert itself in the university context and to be socially appreciated. But this was not the case. Nowadays philologists seem to be obsolescent. Only a few of them refer to themselves as philologists. In the framework of a groundbreaking investigation, Catherine Pascale Hummel has recently conducted a series of interviews with researchers and Language and Literature teachers that work in European universities (in Italy, Switzerland, Belgium, France, England and Germany). The answers collected point out that few participants share the same ideal of Philology. Many of them do not even recognize this subject as their main activity. Those who consider themselves philologists are those who 
study the history of language, the classicists (Pascale Hummel, the editor of the volume is herself a well known specialist in the grammar of the ancient Greek) and several medievalists ${ }^{4}$. Outside these limited circles of researchers, almost no one asserts openly his or her philological identity from an academic point of view. Moreover, no one asserts that he or she teaches Philology, no matter at what level. This is due to the fact that, unlike what happened 30 years ago, the curricula do not refer to any kind of philological background, either at the undergraduate or postgraduate level ${ }^{5}$.

Considered in its totality, the above mentioned volume does not stand for an enthusiastic profession of faith with regard to the future of this discipline. The main reason that could explain this decline is related to the utility of ideas and knowledge that are confined to less common preoccupations $^{6}$. Therefore, one is not compelled to believe in such a drastic diagnosis. No one from São Paulo or Coimbra was interviewed in this study called La Philologie au Parloir. If these two lusophone universities had been included in the study, the number of "believers" might have increased a little bit. I am mentioning São Paulo because this university can pride itself on a remarkable philological tradition (in the field of linguistic and literary studies) and on the publishing of the inaugural number of a new journal - Tágides - that programmatically claims to be "neophilological". I am also mentioning Coimbra because here the spirit of D. Carolina is still alive. Critical editions continue to be published in this university ${ }^{7}$. The journal Revista Portuguesa de Filologia continues to be issued although nowadays this happens more irregularly. Founded in 1947 be Manuel de Paiva Boléo, this journal has been for decades a space of confluence and collaboration between linguists and literary scholars.

It is common knowledge that every morning, when she enters her study where she devotes herself to her work, a female philologist from Coimbra dresses into a white overall.

The whiteness of her overall is not an aleatory signal. It has to do with the old ideals of Philology: rigour and detachment, useful work, attentive preparation of texts that represent an elevated product of the human mind. At least some people continue to see Philology as a descriptive subject, taxonomic, comparative and, above all, empirical and based on documentation. This is the status Philology had when D. Carolina was 
teaching at the University of Coimbra. This is the reason why Philology requires coming in contact with old sheets of paper that need to be handled with great care and aseptically (apart from the overall, protective gloves are required).

Apart from considering herself a philologist, our colleague that wears the white overall admits being a linguist. The conjunction of these two disciplines is not a question of etymological coherence. The idea of the primacy of language dates back at least to Herder (to whom Philology owes the most significant part of its methodological ethos) and is related to the assumption according to which documents "speak" for themselves ${ }^{8}$.

Due to this primacy of language Philology became more permeable to other fields of knowledge, but at the same time literary studies came to be regarded with certain disbelief. I am referring especially to modern and contemporary literature that has not been included yet in the world's cultural heritage. Thus, it is not surprising that the simultaneous setting up of Philology Departments in Germany, England and the United States around 1870, was centred on language and not literature ${ }^{9}$. It was only later, around the middle of the $20^{\text {th }}$ century that Literature began to be part of philological studies. However, the literature under study was that produced before the $18^{\text {th }}$ century and its corpus served as a basis for the reconstruction of different stages of language.

Why is then so difficult for Philology to live in harmony with literary studies? The first difficulty is undoubtedly related to the relative rebellion that literary studies have always manifested with regard to empiricist epistemology: the spirit of belles lettres and rhetoric was expressed as critical and essayistic judgements that excluded any scientific approaches. As a young university discipline, Philology could not deal with literature from a non-scientific angle. It could regard it as a special linguistic phenomenon or even as a starting point for a minute identity exploration, which was done by some scholars that, apart from being philologists from a restricted point of view, were also literary historians. But that is all. I am inclined to believe that this is the root of many confusions and suspicions that have been increasing for the last years, leading to a serious disbelief among linguists and literary scholars ${ }^{10}$.

Nevertheless, philologists did not stop dealing with literature. First of all, they were choosing the texts to be studied. Establishing a text correctly and 
identifying the existing variants is not tantamount to cleaning the façade of a dirty monument. It also requires deciding which materials can be interpreted. This is the reason why all the philologists of the $19^{\text {th }}$ century dedicated themselves to this great task. For instance, the two main works of D. Carolina are the critical editions of Cancioneiro da Ajuda and Poesias by Sá Miranda. D. Carolina worked hard on a third work but she did not manage to finish it: the critical edition of the Compilaçao Vicentina ${ }^{11}$.

Starting from literary texts, philologists used to carry out other tasks. I am referring to the critique of sources which they would always employ from a probative angle. From this perspective, the text used to function as a palimpsest filled with original clews that had to be brought to light. Most of the time, it was a question details to which philologists were extremely attentive. What was Gil Vicente's source of inspiration for Barcas? This is what Paulo Quintela and Eduard Beau asked themselves in Coimbra, 80 years ago. Did Camões read Plato? inquired professor Costa Pimpão and his irreverent student Vergilio Ferreira. Difficult as it might have been to answer such questions, the answers could not be speculative. On the contrary, they had to be sustained by concrete facts.

Other philologists followed a different path, turning the text into an access way to the ethnos and conceiving Philology as a field that included the entire production of the human mind ${ }^{12}$, a sort of generous mantle under which there was enough room for language, culture, philosophy, human geography and history ${ }^{13}$. Well, everything or almost everything. Nowadays it is usual to refer to this type of philology (Wortphilologie) by using depreciatory words such as "imperial" or "deterministic"14.

I remember having met a great philologist during the period when I began studying Gil Vicente and did not know very well what path I was supposed to follow. Then, during a summer course in Santander, Don Alonso Zamora Vicente told me: "In Gil Vicente you should be looking for the life of ordinary people. The way they speak, their complaints, their fears. Gil Vicente is a man of the people and this is something that cannot be denied". In my Vicentian inquiries I always took his piece advice into consideration. I knew it comprised an intuitive component, as well as a more rational one. However, I knew that, above all else, his piece of advice derived from a comprehensive approach that regarded literature as an integral part of a vast culture where many components could enter. Apart 
from the valuable incentive offered by his piece of advice, the words of Dom Alonso revealed the philological matrix to which he belonged, representing a kind of revelation, since they pointed out the cultural identity of the author. In fact, reading Gil Vicente while taking into consideration such a warning compels one to look for different research approaches.

As mentioned above, literary studies are rebellious. Maybe the nature of their object of study caused this Promethean insubordination and made them have a special status in the framework of the Humanities. Initially sheltered by Philology, literary studies could have contented themselves with this cautious respectability. But this was not the case. They aimed higher and sought their independence. First they found it in literary history, borrowing the great narratives that followed a Hegelian matrix (in the Portuguese case, for example, everything led to Camões and everything resulted from him, suggesting a matrix that for some was Celtic, for others was Arabic and mixed for those who were the least resolute) ${ }^{15}$. However, apart from sliding towards political benefits, the organic and teleological diachronism paid little attention to the text. The textualists (structuralists and stylists) reacted to this neglect to such an extent that it may be assumed that it was this lack of contextual regulation that, at a certain moment, made literary studies move away from Philology.

Actually, although bound up with the historical substrate, Philology was seen as a hindrance for those textualists that aimed at deciphering the text and that, at a certain moment, took possession of literary studies ${ }^{16}$. This situation took place in a relatively stable context. Undoubtedly, there were changes going on, but they were slow, predictable and always very controversial. Meanwhile, the entire field of the Humanities changed. It is significant that a new subfield was created, one whose aim was to reconstruct its history, diagnose its weak points and foresee its future ${ }^{17}$. Despite their well-known tendency towards self-oriented reflexivity, literary studies are gradually being valorized, with regard to both their institutional and methodological dimension. The reconstruction of its history, in particular, provided important elements for up-to-date debates.

Apart from all the sociological and technological changes that have occurred in the last decades (and also because of them), there is no doubt 
José Augusto Cardoso Bernardes, Perennial Philology and the Ideal...

HSS, vol. IV, no. 3 (2015): 55-72

that the Humanities still play a crucial role in research, as well as at the different levels of the teaching process.

The utility of the philological work can be more easily justified in the research field. It is still necessary to investigate the works inherited from previous writers. More concretely, I am referring to the works of Almeida Garrett that are kept, in their majority, in the General Library of the University of Coimbra and proved to be indispensable for the accomplishment of the critical edition of the works of the author. Nonetheless, investigating the works inherited from other philologists is also legitimate. This time I am referring to the works of D. Carolina Michaëllis de Vasconcelos that kept in the same library and include various autographs, working plans, spare notes, comments on books, as well as an extremely rich correspondence with almost all the Iberian philologists of that period ${ }^{18}$. If studying the "papers of Garrett" turns to be indispensable to the consolidation and renewal of the global knowledge of his work, the contact with the documents of D. Carolina is extremely important in order to justify her choices and clarify some of the stances the German professor adopted on disputed issues, such as textual and contextual aspects ${ }^{19}$.

Contrary to what happened in the European countries in general, the Portuguese philology (for reasons related to the institutional devitalization and the belated affirmation of the university field of Letters) did not manage to produce the desired results ${ }^{20}$. Apart from the widely known scarcity of critical editions, there are many Portuguese authors about whom there are not even reference editions, with regard to both the selection of the texts and the prefatory studies and the annotations made. It is also significant that, following the series of volumes published prior to the 60's in Coleção dos Clássicos Sá de Costa and despite many attempts, there were no other similar achievements in terms of perseverance, comprehensiveness and seriousness.

If no significant doubts can be cast on the utility of Philology in the research field, the same does not apply in the teaching field. This is especially the case of primary and secondary school. The authors of the handbooks pay little attention to reliable editions when they establish the content of their anthologies. In many cases the above mentioned handbooks do not even mention the editions they are based on (as if attributing a sonnet to Camões when the author is someone else did not 
José Augusto Cardoso Bernardes, Perennial Philology and the Ideal...

HSS, vol. IV, no. 3 (2015): 55-72

matter at all or as if its accurate transcription were of no importance). Even when they recommend a complete work to students (Os Maias, for instance), it seems that it does not matter whether they use a reliable edition or not. The lack of this care is a sign that our philological sensitivity has started to whither away. It should be also noted that regarding this problem a considerable percentage of teachers have never had the opportunity, either at the beginning of their career or during their continuous learning, to be made aware of the importance of such aspects, both from the patrimonial point of view and the critical and interpretative one.

This is another aspect of the problem. Indeed, during the last two decades Philology has basically disappeared from the Portuguese university context. University teachers that are researchers too cannot keep away from such problems. This is the reason why especially those who deal with "old" texts need to be up-to-date with the results yielded by philological investigations. What matters is to know if teachers do what they are supposed to in order to stimulate the same attitude in their students. As Aguiar e Silva noted, the lack of Philology disciplines in Language and Literature courses reflects the fact that at a certain moment the Faculties of Letters hurried to eliminate one of their strongest matrices ${ }^{21}$. This does not mean that some teachers do not include in their syllabi small philological modules. However, generally, these are only introductory segments whose goals, teaching methods and types of evaluation are not well structured. This situation cannot foster the philological sensitivity of students ${ }^{22}$.

\section{Explanations: pragmatism and the cult of interpretation}

What might have contributed to this state of affairs that, without being typical of Portugal, is more noticeable in our country? Irrespective of other causes that can be advanced here (one could refer, for example, to the widely known contempt for the patrimonial values or to the lack of conditions that are required in order to complete long and demanding research tasks), the main explanation I can think of is related to the two tendencies manifested in the field of the Humanities: pragmatism and the cult of the interpretation.

Actually, at first sight, the advantages Philology provides do not seem to find echoes in the university context that is increasingly becoming more 
oriented towards social and economic benefits. If, in their totality, the Humanities are regarded with disbelief, disciplines such as Philology are even more wronged from this point of view. Who is interested nowadays in knowing whether Crisfal was written by Bernardim, Cristóvão Falcão or by a less important writer? It is very important to know whether Gil Vicente staged his Auto da Visitação in the presence of the Queen D. Leonor de Lencastre, the widow of D. João II or whether the "old queen" that was in the chamber on the evening of the $7^{\text {th }}$ of June of 1502 was Infanta D. Brites, Duchess of Beja and mother of the King D. Manuel. Does it matter that in Barca do Inferno the silly Joane gives different answers in the edition of 1519 and in the version included in Livro das Obras (the Angel asks: "Who are you?" and in the first version Joane answers: "Maybe someone", while in the second version his answer is: "No one"). Are these important questions? To what extent can we make them matter? More concretely, how can we answer the ruthless question that is being asked nowadays whenever knowledge is under public scrutiny: "What's the use of all this?"

Another cause that can explain the devitalization of philological studies is related to the importance given to interpretation. Many of those who feel the need to legitimate the Humanities among other university disciplines resort to a major argument: the disciplines of this area set up a critical attitude towards texts, but also towards the world. Thus, literary texts (but also philosophical texts) seem to have the power to bring about decipherment practices.

Shifting the legitimacy of the humanistic disciplines towards the hermeneutical level (and basically only towards this level), the protagonists that adopt such a stance belittle other dimensions that, during decades, have been associated with this field. I am referring especially to its identity. Before interpreting a text it is necessary to study its materiality and its cultural substrata. This was supposed to be the work of philologists. Nowadays such a contribution seems to be dispensable.

This issue has become quite a bone of contention. It is common knowledge that the philological tradition was particularly cautious whenever interpretation came into question. The reasons for this cautiousness were clear: the type of work that was being done lacked objectivity and thus could easily be prone to essayistic subjectivity. In the 
80's the reluctance among philologists to interpretation was caused by their need to delimit themselves from the tradition coming from the field of rhetoric (even the one that favoured the description of textual mechanisms), as well as from the tradition of Belles Lettres that was centred on the paraphrastic commentary, more or less free. None of these activities were welcome to be part of en empirical discipline, such as Philology.

This rejection gradually led to a series of difficulties that Philology had to face in the university context. The first step towards the intensification of these difficulties consisted in admitting the equipollence between old and modern or contemporary texts. There is no doubt that the inclusion of more recent texts in literature courses at the university relegated the philological work to a secondary role. Contrary to what happened with older texts, the recent ones could be revised by the author and, above all, did not lack a contextual framing ${ }^{23}$.

Secondly, there is no doubt that such a change was challenging. This challenge emerged at the beginning of the 60's and then turned immediately into a cause, first generational (old philologists were regarded as guardians of the meaning of texts and thus they were included in antidemocratic hosts) and then civilizational, winning identity rights in occidental universities.

However, nowadays the force of this dichotomy seems to be less intense. The impression is that an important part of the debates it originated (and some of them are rather famous) resulted from a series of ambiguities. This does not mean there is no room for dissidence. The philologists that are more genuine continue to regard interpretation with suspicion and, in their turn, the hermeneuts that express more enthusiasm continue to not be so interested in the philological work since they regard it as specious, especially in the current context that is harmful to the Humanities $^{24}$.

The initial disagreement being overcome, it seems that there is room for compromise. The formative and hermeneutical potential of the interpretation process can now be recognized. However, it is also reasonable to think that the contribution of Philology to literary studies did not lose its acuity, neither in the research field, where this prerequisite is more salient, nor in the teaching field. As far as the area of investigation is concerned, it is still necessary to work starting from texts that are not 
assessed critically. Being highly specialized, the work of philologists continues to be indispensable when it comes to editing and identifying a text. Without this kind of work, no further step can be made towards another stage of cultural integration. Even if one admits that the concept of science has evolved, progressively separating itself from the positivist model, it is still necessary to maintain certain ethics of rigour. And in the entire history of literary studies Philology is the most capable of providing such ethics. It is important to be aware of this accuracy, precisely when the progress of digital technology has started to facilitate the work of philologists, which could lead to a relaxation of their methods of investigation.

The qualified effort of philologists is also important in the teaching field. It is not only a question of teaching texts in a faithful way. It is also a question of conceiving the texts as a workshop product that is translated into matter and spirit. By force of circumstances, students limit themselves to studying contextual fragments, ignoring the entirety of the material object they proceed from. This frequently leads to a distorted perspective on the process of creation and literary circulation. Explaining to students that, before appearing in their handbook, a certain sonnet appeared in another type of publication, making them aware of the fact that there are doubts regarding its form or even its author, may stand for an important stage in acquiring a sense of interpretation. On the other hand, the fulfillment of this stage will reinforce the truth that must guide the teaching of literature. If well-balanced, this component will facilitate students' adherence to a dimension that is far from being merely technical. Enabling the students to see and touch an old book, for example, is tantamount to allowing them to enter an alluring world by telling them that literature entails difficulties and, contrary to what is believed, it is far from being a completed revelation. Gumbrecht (2004) insistently refers to this retrieval of materialities (or of what is present), emphasizing its importance with regard to the credibility that should characterize the research field and the teaching process.

Therefore, the rights of the young reader in relation to the dialogue with the text should not be suppressed. It is enough to combine the exercise of these rights with the attention paid to other dimensions. 
José Augusto Cardoso Bernardes, Perennial Philology and the Ideal...

HSS, vol. IV, no. 3 (2015): 55-72

\section{Conclusion}

In order to assert themselves in the university context, literary studies had to pass a series of difficult validation tests. In the $19^{\text {th }}$ century the epistemological support of the discipline had an inevitable positivist nature. This is what happened in relation to the symbiosis between Philology and Literary History. At a certain moment, this symbiosis was accused of suffering from naivety and weakness in the framework of the Humanities that were more and more enthralled by the Grail of the meaning, valorizing less and less the patient and minute investigation that so frequently yields "modest" results.

Nowadays there is no doubt that literary studies need to be legitimated again. Being aware of this necessity, there are voices that denounce the regress registered by Philology. Some of these voices, implicitly or explicitly, deplore a certain methodological laxity that has proliferated in the field of literary studies. Other voices reflect the enthusiasm for the possibilities offered by the digital novelties that enable philologists not only to recover their ambition, but also to develop it. Actually, far from being just a Trojan Horse, digital technologies open a new era, setting philologists free from jotting notes down on cards and from the slow (and fallible) collation between versions. Helped by programs that allow reaching reliable results, at least as far collation is concerned, nowadays researchers (that before used only a camera) can carry out tasks that, a few years ago, seemed mirific ${ }^{25}$. In some cases, and perhaps this was one of the biggest achievements of technology, philologists can carry out their tasks without going to the archive where the original documents are being kept.

Be that as it may, nothing can replace the necessity of philologia perenis, useful from the civic point of view: humble, hard-working, synergic, patrimonial, instead of the so-called "imperial" discipline, as idealized first by the European humanists and then by the great German philologists of Jewish origin Léo Spitzer (1887-1960) and Erich Auerbach (1892-1957). The common link will always be the utopia of the Truth that contrasts with the obvious nature of the Error. Philology aimed at correcting numerous errors. Undoubtedly, nowadays the Truth is a horizon, not a goal. That is why it is important to talk about a stimulating horizon and not about a point of reference that is vague or only plausible. 
Is the white overall really necessary? No, if it alludes to the aseptic environment typical of hospitals and laboratories (such an environment could be beneficial to the Humanities, but would never belong to them). The answer is positive if by "white overall" we understand the honest need to differentiate clearly between our idiosyncrasy and the search for the arithmetic truth. And there are always at least two practical aspects: like any other uniform, the overall enhances the sense of belonging to a certain community. In this case it is a community of people that spend a lot of time reading in order not to entertain themselves or improve their mind, but to better understand the ciphered reality of the world. At the same time, this overall keeps clean the clothes of those who work with ink and forestall uncontrolled tendencies towards subjectivity.

Literary studies must approach Philology from the angle of this equilibrium of passo doble 26 that is doomed to instability. The aim would be not to imitate it completely, but to draw on the compromise Philology can ensure between rigour and sharpness, comprehensiveness and profundity, autonomy and heteronomy, investigation and education. 
José Augusto Cardoso Bernardes, Perennial Philology and the Ideal...

HSS, vol. IV, no. 3 (2015): 55-72

\section{Annexes}

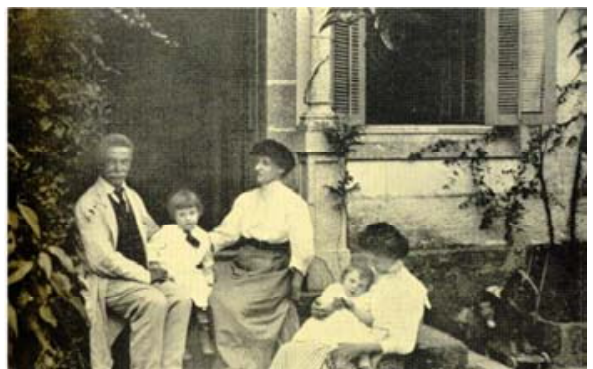

Fig. 1

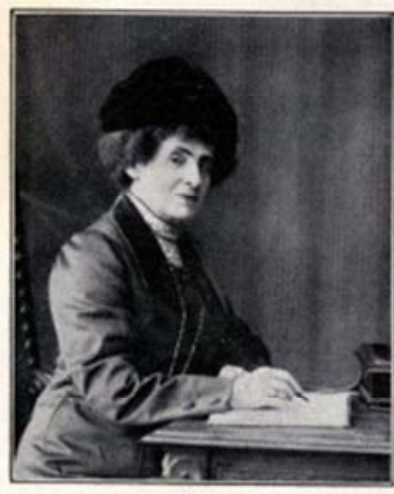

Fig. 2

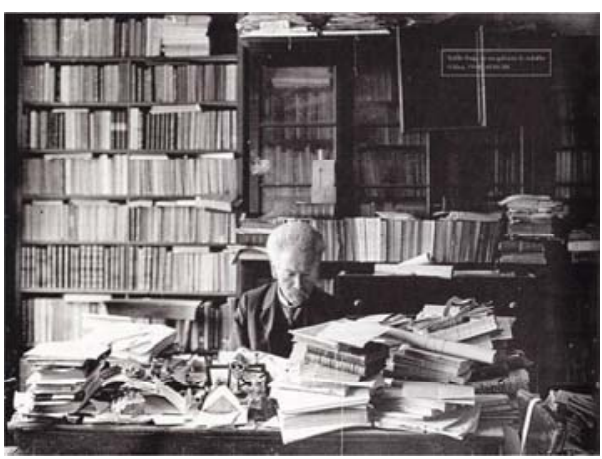

Fig. 3

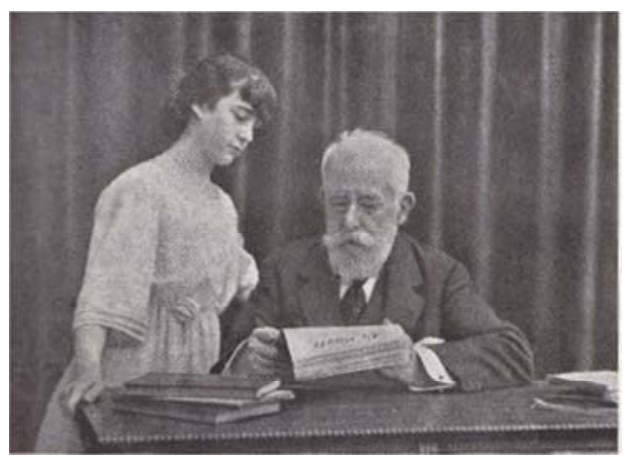

Fig. 4

\section{References}

Bernardes, J. A. C. (2011). “Os Estudos Literários na Universidade”. Pensar a Liter@tura no século XXI. João Amadeu Carvalho da Silva, José Cândido de Oliveira Martins \& Miguel Gonçalves. Orgs. Braga, Faculdade de Filosofia. 27-52;

Blecua, J. M. (red.) et alii. (1999). Filología e informática. Nuevas tecnologias en los estúdios filológicos. Madrid: Editorial Milenio S.L.

Buescu, H. (2013). Experiência do incomum e boa vizinhança. Porto: Porto Editora.

Citton, Y. (2007). Lire, interpréter, actualiser. Pourquoi les etudes littéraires?. Paris: Éditions Amsterdam. 
José Augusto Cardoso Bernardes, Perennial Philology and the Ideal...

HSS, vol. IV, no. 3 (2015): 55-72

Citton, Y. (2010). L'Avenir des humanités. Économie de la connaissance ou cultures de linterprétation?. Paris, La Découverte.

Camões, J., and Sales, J. N. (2010). “Who's in a name”. in A Custódia de Belém. 500 anos, Lisboa: Museu Nacional de Arte Antiga.

Crane, G. et alii (2013). "ePhilology: When The Books Talk to Their Readers", $A$ Companion to Digital Literary Studies (Edited by Ray Siemens and Susan Schreibman). London: Wiley-Blackwell, pp. 29-64.

Cunha, C. F. da. (2002). A construção do discurso da história literária portuguesa no século XIX. Braga: Centro de Estudos Humanísticos.

Cunha, C. F. Da (2009). O nascimento da literatura portuguesa, Braga: Nova Educação. Earle, T., F. (2013). "Dois comentários setecentistas sobre a obra poética de Francisco de Sá de Miranda". Estudos sobre cultura e literatura portuguesa do Renascimento. Coimbra: Imprensa da Universidade. 91-105;

Espagne, M. and M. Warner. Sous la direction de. (1998). Philologiques I. Contributions à l'bistoire des disciplines littéraires en France et en Allemagne au XIX siècle.

Franco, M. A., dir. (2011). Tágides. Revista de Literatura, Cultura e Arte Portuguesas. Programa de Pós-Graduação em Literatura Portuguesa da USP.

Funaioli, G. (2007). Lineamenti di una storia della Filologia a traverso $i$ secoli. Bologna: Zanichelli Editore.

Graff, G. and M. Warner. Orgs. (1989). The Origins of Literary Studies in America. A Documentary Anthology. London: Routledge.

Guillory, J. (2002). "Literary Study and the Modern System of Disciplines", in Amanda Anderson and Joseph Valente (edited by), Disciplinarity at the FIN DE SIËCLE, Princeton, Princeton University Press.19-43.

Gumbrecht, H. U. (1986). "Un souffle d'Allemagne ayant passé: Friedrich Diez, Gaston Paris and the genesis of national philologies". Romance Philology. XL. 1. 1-37.

Gumbrecht, H. U. (1998). "The Origins of Literary Studies and their End". Stanford Humanities. Review 6. 1. 1-10.

Gumbrecht, H. U. (2003). The Powers of Philology. Dynamics of Thextuality Scholarship. Illinois: University of Illinois.

Gumbrecht, H. U. (2004). Production of Presence. What Meaning Cannot Convey. Stanford: Stanford University Press.

Hummel, P. (2000). Histoire de l'histoire de la Philologie. Étude d'un genre épistémologieque et bibliographique. Genève : Droz.

Hummel, P. (2009). Philologia. Recueil de textes sur la philologie. Paris: Philologicum.

Hummel, P. (2011). La Philologie au parloir. Entretiens réalisés para Pascale Hummel. Paris: Philologicum. 
José Augusto Cardoso Bernardes, Perennial Philology and the Ideal...

HSS, vol. IV, no. 3 (2015): 55-72

Harpham, G. G. (2011). The Humanities and the Dream of America. Chicago: University of Chicago Press.

Hummel, P. and Frédéric, G. Textes réunis par. (2008). Études sur les notions de vérité et de fausseté en matière de philologie. Paris : Philologicum.

Llovet, J. (2011). Adios a la Universidad. El eclipse de las Humanidades. Barcelona: Galaxia Guttenberg.

Kernan, A., ed. (1997). What's Hapenned To The Humanities? Princeton: Princeton University Press.

Mainer, J.-C. (2003). La filología en el purgatorio. Los estudios literarios en torno a 1950. Barcelona: Editorial Crítica.

Mcgann, J. (2013). "Coda: Why digital textual scholarship matters, or philology un a new key". The Cambridge Companion to Textual Scholarship (edited by Neil Fraistat and Julia Flanders), Cambridge University Press. 274-2; University, New York/London, w.w. Norton \& Company.

Menard, L. (2010). The Marketplace of Ideas. Reform and Resistance in the American. New York, London: W. W. Norton and Company.

Numerico, T., D. Fiormonte and F. Tomasi. (2010). L' umanista digitale. Milano: Il Mulino.

Prista, L. (2012). "De Jesus ao Campo Grande, entre filologia e literatura". Românica. 21. 17- 56.

Prista, L. (2013). "O ensino linguístico e de literatura". Universidade de Lisboa, Séculos XIX-XX Vol. II (Coordenação de Sérgio Campos Matos e Jorge Ramos do Ó). pp. 982-1085.

Renker, E. (2007). The Origins of American Literary Studies. An Institutional History. Cambridge: Cambridge University Press.

Silva, V., M. Aguiar. (2010). As Humanidades, os Estudos Culturais, o Ensino da Literatura e a politica de Lingua Portuguesa. Coimbra: Livraria Almedina.

Silvestre, O. M. (2012). "O ensino da literatura contemporânea na universidade. O caso americano". Românica. 21. 57-80.

Todorov, T. (2002). Devoirs et délices. Une vie de passeur. Entretiens avec Catherine Portevin. Paris: Editions du Seuil.

Varvaro, A. (2012). Prima lezione di filologia. Roma-Bari: Gius, Laterza \& Figli.

Vecchi, R. (2012). "Bolonha em Bologna (Um ponto de vista disciplinar)". Românica. 21. 81-90.

Verdelho, T. (2013). "A Língua e a Literatura. Reflexões para uma pedagogia coalescente". Revista de Estudos Literários. 3. 23-64.

Warner, M. (1990). "A propos de la notion de philologie moderne. Problèmes de definition dans l'espace franco-alemand". Philologiques I. Contribution à l'bistoire des disciplines littéraires en France et en Allemagne au XIX e siècle, dir. De Michel 
José Augusto Cardoso Bernardes, Perennial Philology and the Ideal...

HSS, vol. IV, no. 3 (2015): 55-72

Espagne e Michael Warner, Paris: Editions de la Maison des Sciences de l'Homme.

\section{Biographical note}

Jose Augusto Cardoso Bernardes (n. 1958) is Professor at the Faculty of Letters in Coimbra and director of the General University Library. He has carried out his academic carreer at the University of Coimbra: BA in Modern Languages and Literature, Portuguese and French (1980), MA in Portuguese Literature (1985), $\mathrm{PhD}$ in Portuguese Literaturesa (1995) and Agregado (2003). He was President of the Scientific Council of the Faculty (2004-2007) and elected member of the general Council of the University (2008-2012). He is now a member of the National Council for Education. Among his publications: Revisões de Gil Vicente (2003), A Literatura no Ensino Secundário (2004), Gil Vicente (2008), Gil Vicente, pastor e filósofo (2010) e A Literatura e o Ensino do Português (with Rui Mateus), 2013.

(Article translated from Portuguese to English by Laura Ciochina) 